\title{
First Ever Data on the Occurrences of Acrididae (Acridoidea: Orthoptera) Grasshoppers in the North West Region of Cameroon
}

\author{
Seino Richard Akwanjoh (Corresponding author), Njoya Moses Tita \\ Department of Biological Sciences, Faculty of Science, The University of Bamenda, \\ P.O. Box 39 Bambili - Bamenda, North West Region, Cameroon. \\ E-mail: raseino@yahoo.co.uk
}

Received: July 17, 2019 Accepted: February 1, 2020

doi:10.5296/jbls.v11i1.16432 URL: https://doi.org/10.5296/jbls.v11i1.16432

\begin{abstract}
This article is a pioneer checklist of Acrididae species in the North West Region of Cameroon. This study was prompted by the absence of information on Orthoptera fauna that are found in this region. From November 2016 to September 2017, grasshoppers were collected by hand picking and the help of sweep nets from fields, lawns, farms and vegetation surrounding farms in the capital towns of the seven divisions that make up the region. Seventeen (17) species were captured and identified. These included: Acrida turrita, Coryphosima stenoptera product, Gymnobothrus temporalis, Odontomelus kamerunensis, Roduniella insipida (Acridinae), Catantops melanostrictus, Catantopsilus elongatus, Oxycatantops spissus, (Catantopinae), Cyrtacanthacris aeruginosa, Ornithacris pictula (Cytacanthacridinae), Eyprepocnemis plorans (Eyprepocnemidinae), Acrotylus patruelis, Gastrimargus africanus, Heteropternis thoracica, Trilophidia conturbata, Morphacris fasciata (Oedipodinae) and Afroxyrrhepes obscuripes (Tropidopolinae). Acridinae and Oedipodinae were the most abundant subfamilies with 5 species each. The seventeen (17) species identified in this study were recorded for the first time from the North West Region of Cameroon with one of them Ornithacris pictula magnifica recorded for the first time in Cameroon.
\end{abstract}

Keywords: Checklist, Acrididae, Species, North West Region, Cameroon

\section{Introduction}

Acrididae is an important family in the order Orthoptera, suborder Caelifera, and superfamily Acridoidea. This family is widely distributed in Africa, South of the Sahara. Grasshoppers in the family Acrididae are the most renowned enemies of man because of their pest activities. They are known to destroy both food and cash crops. In addition, grasshoppers form 
important links in food chains and their ease of sampling makes them potentially useful bioindicators of environmental changes. They exhibit entomophagy with some species serving as food to humans (Anderson et al., 2001; Ladeji et al., 2003; Verma and Agarwal, 2005; Banjo et al., 2006; Benkenana and Harrat, 2009; Ronghang and Ahmed. 2010). Acrididae is one of the largest and dominant groups of insect herbivores worldwide (Lecoq, 2010; Bruno et al., 2017). They inhabit preferably open and semi open vegetation where sun rays reach the ground directly thereby raising temperatures and there is sufficient food supply (Bruno et al., 2017). Acrididae is also the largest African family of Orthoptera with over 177 genera containing 403 species in West and Central Africa. The subfamilies Acridinae (33 genera \& 72 species), Catantopinae (30 genera \& 76 species) and Gomphocerinae ( 22 genera $\& 52$ species) are the most diverse. The least diverse subfamilies include Spathosterninae, Euryphyminae, Egnatiinae and Eremogryllinae, each with only one genus (Mestre and Chiffaud, 2009; Lecoq, 2010).

The biodiversity of grasshoppers has been changing in the North West Region of Cameroon in recent times due to increased environmental degradation resulting from human activities such as clearing of virgin bushes for farming, bush fires, construction of roads and buildings. The use of chemicals to control pests and weeds, soil erosion, landslide and overgrazing has contributed much to habitat degradation (GP-DERUDEP, 2006). This encroachment into the natural habitats of the grasshopper species has determined the survival of many grasshopper species.

Available information indicates that most the Acrididae species from Cameroon so far studied have been deposited only in European and American collections. The distribution maps of Mestre and Chiffaud (2009) indicate that most collections have been made from the southern coastal regions of Cameroon. Regions such as the North West have been neglected probably because they were not easily accessible. In this wise, the Acrididae grasshopper diversity in the North West Region of Cameroon is yet to be assessed. The present study was therefore designed to carry out a survey on the short horn Acrididae grasshoppers in the North West Region of Cameroon with the aim to preparing a checklist.

\section{Materials and Methods}

\section{Collection sites}

The North West Region (Figure 1) is one of the ten regions of the Republic of Cameroon. This region lies between latitudes $5^{\circ} 43^{\prime \prime}$ and $7^{\circ} 9^{\prime \prime} \mathrm{N}$ and longitudes $9^{\circ} 13^{\prime \prime}$ and $11^{\circ} 13$ 'E and it covers an area of about $17,400 \mathrm{~km}^{2}$. It is boardered in the North and West by the Federal Republic of Nigeria, in the South by the Western and South Western Regions of Cameroon and to the East by Adamawa Region of Cameroon. 


\section{Macrothink}

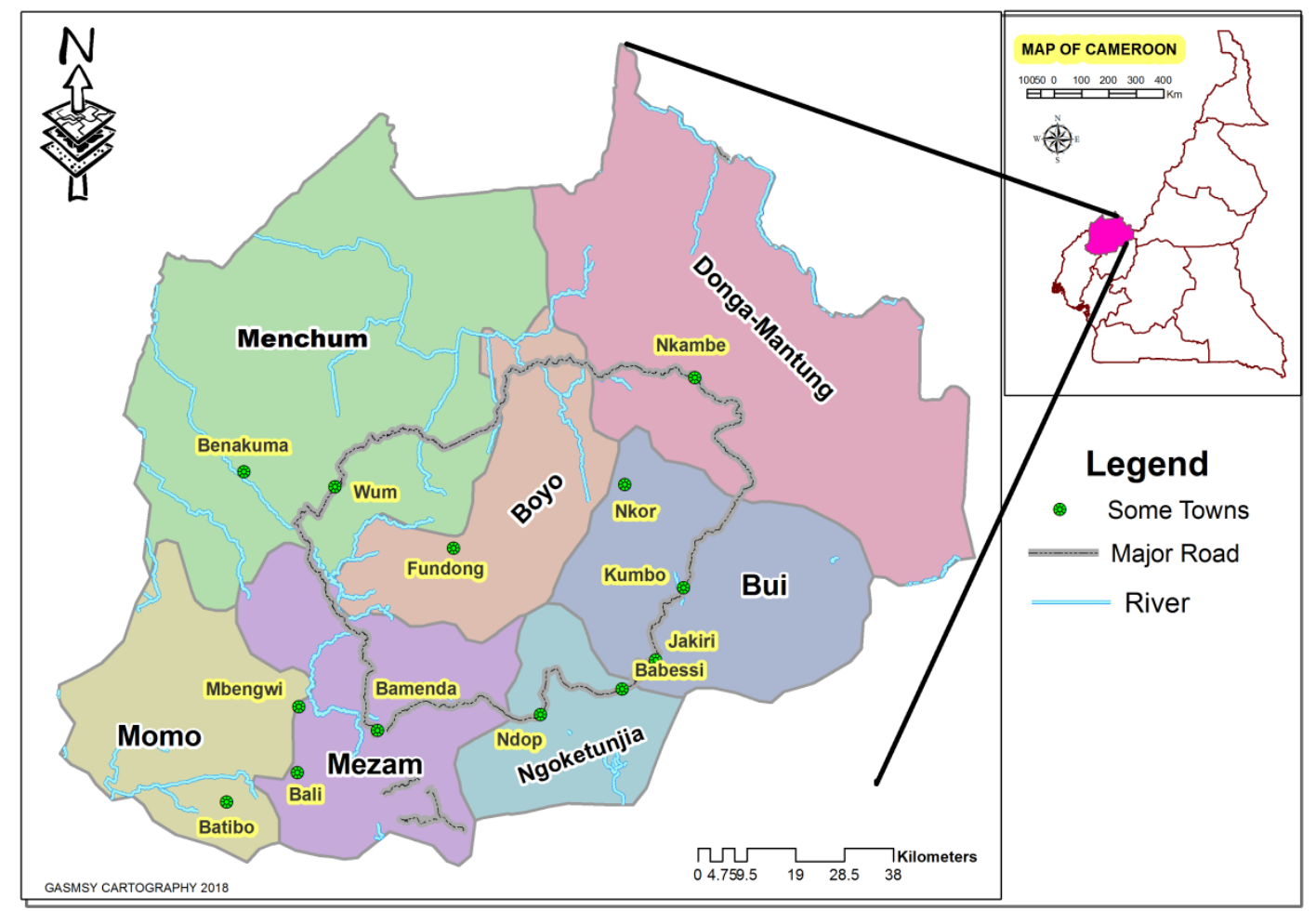

Figure 1. Map of the sampling localities in the North West region of Cameroon

Altitude varies greatly in the North West Region ranging from depressions lower than $400 \mathrm{~m}$ to mountains about $3000 \mathrm{~m}$ above sea level. Vegetation is primarily Savannah with scattered woody areas of shrubs and forest in the lower non mountainous areas. The climate which is greatly influenced by the topography of the region is tropical to transitional in mountainous areas but humid to warm in southern lower zones. Temperatures in high altitude zones are often less than $15^{\circ} \mathrm{C}$ but may exceed $30^{\circ} \mathrm{C}$ in low altitude areas. Average yearly temperature is $27^{0} \mathrm{C}$. The North West Region has two seasons that include a rainy season (mid-March to mid-October) and a dry season (mid-October to Mid-March) with annual rainfall that varies from $1300 \mathrm{~mm}$ to $3000 \mathrm{~mm}$ (Neba, 1991; GP-DERUDEP, 2006).

\section{Materials}

The materials used for the collection of the grasshoppers included a $60 \mathrm{~cm}$ diameter insect sweep net, 1.51 mineral bottle cages prepared by the method of Povpov (1990), a death chamber supplied with cotton wool soaked in Ethyl acetate then covered with a filter paper, a stretching board supplied with pins, and an insect box.

\section{Methodology}

\section{Collection of the grasshoppers}

Insects were collected from the seven divisions that make up the North West Region of Cameroon. The insects were collected between 9 to $11 \mathrm{am}$ and 3 to $5 \mathrm{pm}$ during the period of November 2016 to September 2017. Each Division was visited twice during the period of collection and collection of insects was carried out from at least two locations in the capital 


\section{Macrothink

towns of the Divisions. The locations included fields, farms and on surrounding vegetation.

The specimens were collected with the help of a sweep net and hand picking from vegetation. The specimens were then transported to the laboratory in 1.51 mineral water bottle cages. At the laboratory, the grasshoppers were killed in the death chamber, pinned on the setting boards and labeled. The insects were dried in an oven $\left(60{ }^{\circ} \mathrm{C}\right)$ for one hour.

\section{Identification of the grasshoppers}

Identification was carried out by comparison with previously identified and preserved specimen found in the collections of the Department of Plant Protection, Faculty of Agronomy and Agronomic Sciences (FASA) in the University of Dschang. Confirmation was done by Dr. Kekeunou (Associate Professor), Entomologist in the Department of Animal Biology and Physiology (BPA) in the University of Yaoundé 1, Cameroon. Identified grasshoppers were deposited in the University of Yaoundé 1 collection while some others were used to start a collection in the Department of Biological Sciences, in The University of Bamenda, Cameroon. An annotated list of the collected grasshopper species is given below.

\section{Measurement of sizes of the grasshoppers}

The sizes of the insects were determined on the basis of length. The grasshoppers were then classified as small ( $\leq 2.5 \mathrm{~cm}$ long), medium $(2.5 \leq 3.9 \mathrm{~cm}$ long) and large ( $\geq 4 \mathrm{~cm}$ long). Measurements were made from the tip of the head to the tip of the wing of the grasshopper when folded using a transparent $30 \mathrm{~cm}$ long ruler. An average two individuals were measured per species.

\section{Results}

A total of 17 species from 17 genera and 6 subfamilies (Acridinae, Catantopinae, Cyrtacanthacridinae, Eyprepocnemidinae, Oedipodinae and Tropidolinae) were collected from the 7 divisions of the North West Region of Cameroon. The subfamilies with the highest number of species included Acridinae and Oedipodinae each of them having 5 (29.41\%) of the total species collected. The subfamilies with lowest number of species identified included Eyprepocnemidinae and Tropidopolinae (Figure 2). Each of them had only one species (5.88\%). Ornithacris pictula magnifica (Bolivar, 1882) was collected in Cameroon for the first time. 


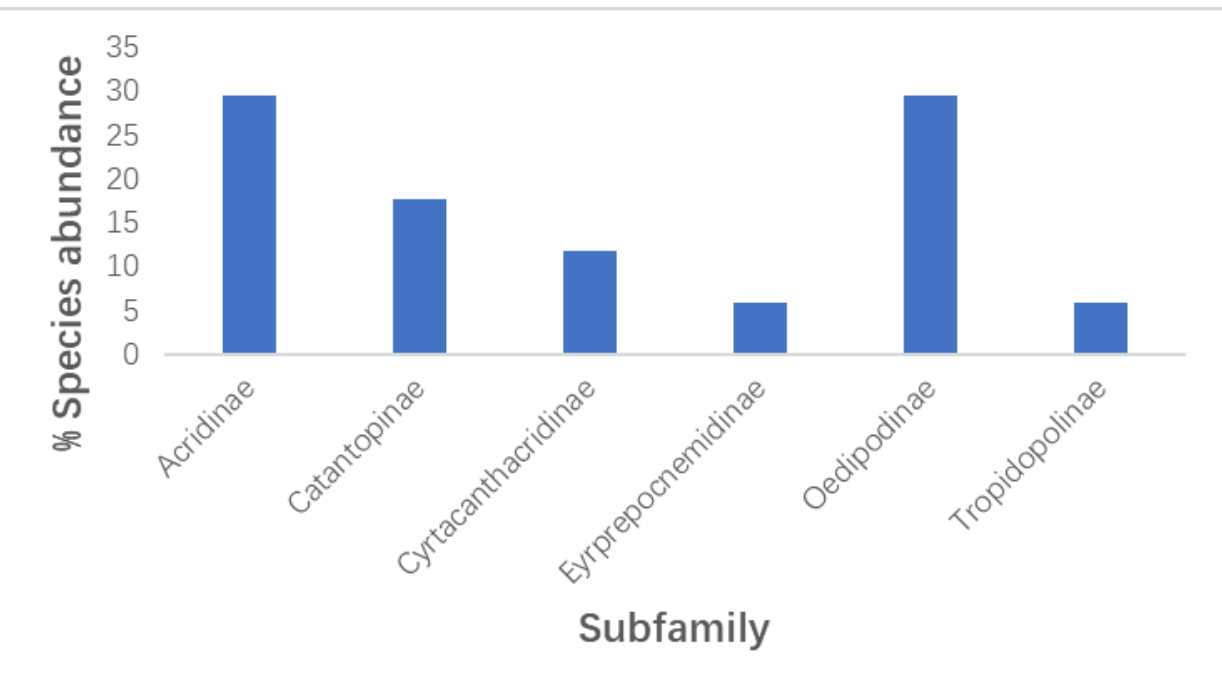

Figure 2. Acrididae species abundance in the North West Region of Cameroon from November 2016 to September 2017

A check list of the Acrididae species collected in the North West Region of Cameroon is shown in Table 1. The information in this table includes the Classification of the species (subfamily, species), the number and sexes of individuals collected per species, reference(s) for previous report on the species in Cameroon, the sizes (large, medium or small) of individuals collected; the ease with which the insects were found at collection sites (habits) and their distribution in Africa.

The grasshoppers collected from the North West region were easily classified into size groups of large, medium and small. Most of the species ( 9 species $=52.94 \%)$ were medium while the large species ( 3 species $=17.65 \%$ ) included Cyrtacanthacris aeruginosa, Ornithacris pictula magnifica and Afroxyrrhepes obscuripes. The small sized species (5 in number) made up $29.41 \%$ of the Acrididae specimens identified in the North West Region of Cameroon. 


\section{Macrothink}

Journal of Biology and Life Science

ISSN 2157-6076

2020, Vol. 11, No. 1

Table 1. Summary of information on seventeen (17) Acrididae grasshoppers collected in the North West Region of Cameroon

\begin{tabular}{|c|c|c|c|c|c|c|}
\hline Subfamilies & Species & $\begin{array}{l}\text { Spe } \\
\text { cim } \\
\text { ens }\end{array}$ & $\begin{array}{l}\text { Reference } \\
\text { s from } \\
\text { Cameroo } \\
\text { n }\end{array}$ & Size & $\begin{array}{l}\text { Habits } \\
\text { in } \\
\text { NWR } \\
\text { of } \\
\text { Camer } \\
\text { oon }\end{array}$ & Distribution \\
\hline \multirow{5}{*}{$\begin{array}{l}\text { Acridinae, } \\
\text { McLeay, } 1821\end{array}$} & $\begin{array}{l}\text { Acrida turrita } \\
\text { (Linnaeus, } \\
1758 \text { ) }\end{array}$ & $\begin{array}{l}8 \hat{\bigcirc} \\
6 \text { 우 }\end{array}$ & $\begin{array}{l}\text { Seino et } \\
\text { al. } 2013 \\
\text { Mestre\& } \\
\text { Chiffaud, } \\
2009\end{array}$ & $\begin{array}{l}\text { Mediu } \\
\mathrm{m}\end{array}$ & $\begin{array}{l}\text { Found } \\
\text { in small } \\
\text { number } \\
\text { S }\end{array}$ & $\begin{array}{ll}\text { - } & \text { All Africa and Mediterranean } \\
\text { (OSF, 2018) } \\
\text { - } \\
\text { Most of sub-Saharan Africa } \\
\text { (acrida.info/PDF2006) }\end{array}$ \\
\hline & $\begin{array}{l}\text { Coryphosima } \\
\text { stenoptera } \\
\text { product } \\
\text { (Karsch, 1893) }\end{array}$ & $9 q$ & $\begin{array}{l}\text { Dirsh, } \\
\text { 1965; } \\
\text { Mestre\& } \\
\text { Chiffaud, } \\
\text { 2009; } \\
\text { Seino et } \\
\text { al. } 2013 \\
\end{array}$ & Small & $\begin{array}{l}\text { Found } \\
\text { in small } \\
\text { number } \\
\text { s }\end{array}$ & $\begin{array}{ll}\text { - } & \text { West, Central, East and South } \\
& \text { Africa(OSF, 2018) } \\
\text { - } & \text { Most of sub-Saharan Africa } \\
\text { (acrida.info/PDF2006) }\end{array}$ \\
\hline & $\begin{array}{l}\text { Gymnobothrus } \\
\text { temporalis } \\
\text { (Stål, 1876) }\end{array}$ & $\begin{array}{l}3 \hat{O} \\
70\end{array}$ & $\begin{array}{l}\text { Dirsh, } \\
1965 ; \\
\text { Mestre\& } \\
\text { Chiffaud, } \\
2009\end{array}$ & Small & $\begin{array}{l}\text { Found } \\
\text { in small } \\
\text { number } \\
\text { S }\end{array}$ & 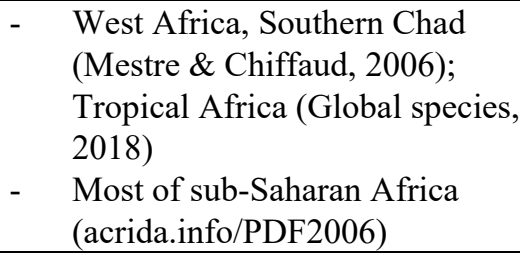 \\
\hline & $\begin{array}{l}\text { Odontomelus } \\
\text { kamerunensis } \\
\text { (Ramme, 1829) }\end{array}$ & $5 q$ & $\begin{array}{l}\text { Dirsh, } \\
1965 ; \\
\text { Mestre \& } \\
\text { Chiffaud, } \\
2009\end{array}$ & $\begin{array}{l}\text { Mediu } \\
\mathrm{m}\end{array}$ & Rare & $\begin{array}{l}\text { Tropical Africa (Mestre \& } \\
\text { Chiffaud, 2006; Insectoid.Info, } \\
\text { 2018) }\end{array}$ \\
\hline & $\begin{array}{l}\text { Roduniella } \\
\text { insipida } \\
\text { (Karsch, 1876) }\end{array}$ & 19 우 & $\begin{array}{l}\text { Dirsh, } \\
\text { 1965; } \\
\text { Mestre \& } \\
\text { Chiffaud, } \\
2009\end{array}$ & Small & $\begin{array}{l}\text { Found } \\
\text { in small } \\
\text { number } \\
\text { s }\end{array}$ & $\begin{array}{l}\text { Africa, East Tropical Africa, } \\
\text { Uganda, Lake Victoria, Sese } \\
\text { Islands (Mestre \& Chiffaud, } \\
\text { 2009; OSF, 2018) }\end{array}$ \\
\hline
\end{tabular}

\begin{tabular}{|c|c|c|c|c|c|c|}
\hline & $\begin{array}{l}\text { Catantops } \\
\text { melanostrictus } \\
\text { (Shaum, 1853) }\end{array}$ & 1 우 & $\begin{array}{l}\text { Seino et } \\
\text { al. } 2013\end{array}$ & Medium & Rare & $\begin{array}{l}\text { - Whole of Africa (Insectoid.Info, 2018) } \\
\text { - } \quad \text { North Cameroon, Tchad } \\
\text { (acrid.info/PDF2006/) }\end{array}$ \\
\hline \multirow[t]{2}{*}{$\begin{array}{l}\text { Catantopinae, } \\
\text { Brunner } \\
\text { vonWattenwyl, } 1893\end{array}$} & $\begin{array}{l}\text { Catantopsilus } \\
\text { elongatus } \\
\text { Ramme, } 1929\end{array}$ & 10 & $\begin{array}{l}\text { Dirsh, } \\
1965 ; \\
\text { Mestre \& } \\
\text { Chiffaud, } \\
2009\end{array}$ & Small & Rare & $\begin{array}{l}\text { - West and Central Africa (Insectoid.Info, } \\
\text { 2018; OSF, 2018) } \\
\text { - } \quad \text { Most of west Africa } \\
\text { (acrida.info.PDF2006/) }\end{array}$ \\
\hline & $\begin{array}{l}\text { Oxycatantops } \\
\text { spissus } \\
\text { (Walker, 1870) }\end{array}$ & $\begin{array}{l}2 \hat{\sigma} \\
3 \text { 우 }\end{array}$ & $\begin{array}{l}\text { Dirsh, } \\
\text { 1965; } \\
\text { Jago, } \\
\text { 1989; } \\
\text { Mestre \& } \\
\text { Chiffaud, } \\
2006 \text {, } \\
2009 ; \\
\text { Seino et }\end{array}$ & Medium & $\begin{array}{l}\text { Found } \\
\text { in small } \\
\text { numbers }\end{array}$ & $\begin{array}{l}\text { - } \quad \text { East, North West and Central Africa } \\
\text { (Insectoid.Info, 2018; OSF, 2018) } \\
\text { - } \quad \text { Most of West Africa, North Cameroon } \\
\text { (acrida.info/PDF2006/) }\end{array}$ \\
\hline
\end{tabular}


al. 2013

\begin{tabular}{|c|c|c|c|c|c|c|}
\hline $\begin{array}{l}\text { Cytacanthacridinae, } \\
\text { Kirby, } 1910\end{array}$ & $\begin{array}{l}\text { Cyrtacanthacris } \\
\text { aeruginosa } \\
\text { (Stoll, 1813) }\end{array}$ & 1 우 & $\begin{array}{l}\text { Dirsh, } \\
\text { 1965; } \\
\text { Johnston, } \\
\text { 1956; } \\
\text { Mestre \& } \\
\text { Chiffaud, } \\
2009 ; \\
\text { Seino et } \\
\text { al. } 2013\end{array}$ & Large & Rare & $\begin{array}{l}\text { - } \quad \text { Nigeria, West Africa, North Africa, } \\
\text { South Africa (Mestre \& Chiffaud, 2006) } \\
\text { - Several subspecies cited for East and } \\
\text { South Africa, C. aeruginosa flavecens and } C \text {. } \\
\text { aeruginosa goldingi cited for west Africa } \\
\text { (acrida.info/PDF2006/) }\end{array}$ \\
\hline & $\begin{array}{l}\text { Ornithacris } \\
\text { pictula } \\
\text { magnifica } \\
\text { (Bolivar, 1882) }\end{array}$ & $\begin{array}{l}1 \delta^{\lambda} \\
29\end{array}$ & $\begin{array}{l}\text { New } \\
\text { Record } \\
\text { for } \\
\text { Cameroon }\end{array}$ & Large & Rare & $\begin{array}{l}\text { - } \quad \text { West, East South Africa (Mestre \& } \\
\text { Chiffaud, 2006; Insectoid.Info, 2018; OSF, } \\
\text { 2018) } \\
\text { - } \quad \text { Ivory Coast, Guinea, Sierra Leone, } \\
\text { Tchad, Nigeria (acrida.info/PDF2006/) }\end{array}$ \\
\hline $\begin{array}{l}\text { Eyprepocnemidinae } \\
\text { Brunner von } \\
\text { Wattenwyl, } 1893\end{array}$ & $\begin{array}{l}\text { Eyprepocnemis } \\
\text { plorans } \\
\text { (Charpentier, } \\
1825 \text { ) }\end{array}$ & 1 우 & $\begin{array}{l}\text { Dirsh, } \\
1965 ; \\
\text { Mestre \& } \\
\text { Chiffaud, } \\
2009\end{array}$ & Medium & Rare & $\begin{array}{l}\text { - Throughout Africa (Insectoid.Info, 2018; } \\
\text { http://www.iucnredlist.org/details/16084602/1 } \\
\text { - } \quad \text { Sub-Saharan species } \\
\text { (acrida.info/PDF2006/) }\end{array}$ \\
\hline
\end{tabular}

\begin{tabular}{|c|c|c|c|c|c|c|}
\hline \multirow{6}{*}{$\begin{array}{l}\text { Oedipodinae } \\
\text { Walker, } 1871\end{array}$} & $\begin{array}{l}\text { Acrotylus } \\
\text { patruelis(Herric } \\
\text { h-Schaffer, } \\
1838)\end{array}$ & $\begin{array}{l}10 \\
20\end{array}$ & $\begin{array}{l}\text { Dirsh, } \\
\text { 1965; } \\
\text { Mestre \& } \\
\text { Chiffaud, } \\
2009\end{array}$ & $\begin{array}{l}\text { Mediu } \\
\mathrm{m}\end{array}$ & Rare & $\begin{array}{l}\text { - } \quad \text { North, West, East and South Africa } \\
\text { (OSF,2018) } \\
\text { - } \quad \text { All of Africa (acrida.info/PDF2006/) }\end{array}$ \\
\hline & $\begin{array}{l}\text { Gastrimargus } \\
\text { africanus } \\
\text { (Saussure, 1884) }\end{array}$ & $\begin{array}{l}13 \\
0 \\
11 \\
0 \\
q\end{array}$ & $\begin{array}{l}\text { Dirsh, } \\
\text { 1965; } \\
\text { Mestre \& } \\
\text { Chiffaud, }\end{array}$ & $\begin{array}{l}\text { Mediu } \\
\mathrm{m}\end{array}$ & $\begin{array}{l}\text { Found } \\
\text { in } \\
\text { small } \\
\text { numbe }\end{array}$ & $\begin{array}{l}\text { - Worldwide and particularly West and } \\
\text { Central Africa } \\
\text { (https://indiabiodiversity.org/species/show/2 } \\
77270 \text { ) }\end{array}$ \\
\hline & & & $\begin{array}{l}\text { 2009; Seino } \\
\text { et al, } 2013\end{array}$ & & rs & $\begin{array}{l}\text { Africa south of the Sahara } \\
\text { (acrida.info.PDF2006/) }\end{array}$ \\
\hline & $\begin{array}{l}\text { Heteropternis } \\
\text { thoracica } \\
\text { (Walker, 1870) }\end{array}$ & $7 q$ & $\begin{array}{l}\text { Dirsh, } \\
\text { 1965; } \\
\text { Mestre \& } \\
\text { Chiffaud, } \\
\text { 2009; Seino } \\
\text { et al, } 2013\end{array}$ & Small & $\begin{array}{l}\text { Found } \\
\text { in } \\
\text { small } \\
\text { numbe } \\
\text { rs }\end{array}$ & $\begin{array}{l}\text { - } \quad \text { Tropical Africa (OSF, 2018) } \\
-\quad \text { Most of west Africa } \\
\text { (acrida.info/PDF2006/) } \\
-\quad \text { Cameroon (Mestre and Chiffaud, 2009) }\end{array}$ \\
\hline & $\begin{array}{l}\text { Trilophidia } \\
\text { conturbata } \\
\text { (Walker, 1870) }\end{array}$ & 29 & $\begin{array}{l}\text { Dirsh, } \\
\text { 1965; } \\
\text { Mestre \& } \\
\text { Chiffaud, } \\
\text { 2009; Seino } \\
\text { et al, } 2013\end{array}$ & Small & Rare & $\begin{array}{l}-\quad \text { Tropical Africa (OSF, 2018) } \\
-\quad \text { All of West Africa } \\
\text { (acrida.info/PDF2006/) }\end{array}$ \\
\hline & $\begin{array}{l}\text { Morphacris } \\
\text { fasciata } \\
\text { (Walker,1870) }\end{array}$ & 29 & $\begin{array}{l}\text { Dirsh, } \\
\text { 1965; } \\
\text { Mestre \& } \\
\text { Chiffaud, } \\
\text { 2009; Seino } \\
\text { et al, } 2013\end{array}$ & $\begin{array}{l}\text { Mediu } \\
\mathrm{m}\end{array}$ & Rare & $\begin{array}{l}\text { - All of Africa south of the Sahara, } \\
\text { Mauritania, Morocco, Madagascar } \\
\text { (acrida.info/PDF2006/) }\end{array}$ \\
\hline $\begin{array}{l}\text { Tropidopolinae } \\
\text { Jacobson, } 1905\end{array}$ & $\begin{array}{l}\text { Afroxyrrhepes } \\
\text { obscuripes } \\
\text { Uvarov, } 1943\end{array}$ & 19 & $\begin{array}{l}\text { Dirsh, } \\
\text { 1965; } \\
\text { Mestre \& } \\
\text { Chiffaud, } \\
\text { 2009; Seino } \\
\text { et al, } 2013\end{array}$ & Large & Rare & $\begin{array}{l}\text { - } \quad \text { Tropical Africa (OSF, 2018) } \\
\text { - } \quad \text { Sudan, Democratic Republic of Congo, } \\
\text { Uganda, Rwanda, Tanzania }\end{array}$ \\
\hline
\end{tabular}




\section{Discussion}

The Acrididae is the largest African family of the Orthoptera. In Cameroon, this family is known to be made up of 12 subfamilies, 171 genera and 210 species. Of these, only 6 subfamilies, 17 genera and 17 species were collected in the Northwest region. Members of the subfamilies Hemiacridinae, Spathosterninae, Oxyinae, Coptacrinae Calliptaminae, and Gomphocerinae were not found in the North West Region of Cameroon. Mestre and Chiffaud (2009) found the subfamily Catantopinae ( 44 species) followed by Oedipodinae (27 species) and Acridinae ( 21 species) to be most dominant in Cameroon. The result of this study was at variance with this observation. This study revealed that the Acridinae (5 species) and Oedipodinae ( 5 species) were dominant in the North West Region.

The family Acrididae is also popular throughout the world because it includes the most dangerous pest grasshoppers such as the locusts. Of the 17 species recorded in the North West Region of Cameroon, only Odontomelus kamerunensis and Roduniella insipidia have not been recorded in Nigeria, Cameroon's immediate neighbor to the west (insectoid.info/checklist/Acrididae, 2018). Similarly, Gymnobothus temporalis, Odontomelus kamerunensis, Roduniella insipidia, Catantops melanostrictus, Catantopsilus elongatus, Eyrprepocnemis plorans, Gastrimargus africanus, Heteropternis thoracica, Trilophida conturbata and Afroxyrrhipes obscuripes have not been recorded in Cameroons neighbour to the South-East, Gabon (Mestre and Chiffaud, 2009; insectoid.info/checklist/Acrididae, 2018). Finally, only Gastrimargus africanus of the 17 species recorded in the North West Region of Cameroon has been recorded in Cameroon's Eastern neighbor, the Republic of Central Africa.

The subfamilies Cyrtacanthacridinae and Oedipodinae are known to contain a number of very important economic species, the locusts (Gillot, 2005). The Cameroonian Acrididae family has been shown to contain these subfamilies and some of the dangerous pest grasshoppers that include Locusta migratoria, Schistocerca gregaris, Anacridium melanorhodon, Nomadacris septemfasciata, Oedaleus senegalensis and Hieroglyphus daganensis (Showler, 1995; Mestre and Chiffaud, 2009). However, none of these known pest species were found in the North West Region of Cameroon during this survey. Five of the 17 species recorded have been included in the World wide list of edible insects. These species include Acrida turrita, Roduniella insipida, Oxycatantops spissus, and Gastrimargus africanus (http://www.foodinsectsnewsletter.org/pdfs/Worldwidespecieslist15sept2011.pdf, 2011).

The results of this survey indicated that the North West Region of Cameroon has a rich diversity of Acrididae grasshoppers in spite of the high level of human disturbance (GP DERUDEP, 2006) and there is need for conservation of Acrididae species in the Region. Since the present study is a first survey conducted in the North West Region of Cameroon, it presents important baseline information for the Acrididae in this Region of Cameroon. These results are also important because biodiversity inventories can provide information on genetic, ecological, and taxonomic diversity (Caporale et al., 2015) that are fundamental for conservation purposes. 


\section{Conclusion}

The absence of information on the Acrididae fauna in the North West Region of Cameroon prompted this investigation. Grasshopper species were collected from fields, lawns, farms and surrounding vegetation in the capital towns of the seven divisions that make up this region. Seventeen species belonging to seventeen genera in six subfamilies were identified. Even though 16 of these species have been recorded in other regions of Cameroon, they were recorded for the first time in the North West region of Cameroon. Ornithacris pictula magnifica was here recorded for the first time in Cameroon.

\section{Authors' Contribution}

Both authors carried out the collection of the grasshopper. Prof. SEINO RICHARD wrote the article and Dr. NJOYA MOSES edited the write-up.

\section{Acknowledgements}

The authors are grateful to Miss DONGMO Ingrid a PhD Entomology student in the Department of Animal Biology of the University of Dschang, Cameroon and to Dr. KEKEUNOU Sevilor (Associate Professor), and Entomologist in the Faculty of Science of the University of Yaoundé 1, for identification of specimens. We are also grateful to Dr. NTONIFOR Helen, the Head of Department Biological Sciences, in the Faculty of Science of The University of Bamenda, for laboratory space.

\section{References}

Anderson, A. N., Ludwig, J. A., Lowe, L. M., \& Rentz, C. F. (2001). Grasshopper biodiversity and bioindicators in Australian tropical savannas: Responses to disturbance in Kakadu National Park. Australian Ecology, 26(3), 213-222. https://doi.org/10.1046/j.1442-9993.2001.01106.x

Banjo, A. D., Lawal, O. A., \& Songonuga, E. A. (2006). The nutritional value of fourteen species of edible insects in Southwestern Nigeria. African Journal of Biotechnology, 5(3), 298-301.

Benkanana, N., \& Harrat, A. (2009). Contribution to the systematic study of grasshopper fauna (Orthoptera, Caelifera) and some bio-ecological aspects of economic importance of species in the Constantine region (East Algeria). Emir. J. Food Agric, 21(1), 40-47. https://doi.org/10.9755/ejfa.v21i1.5157

Bronu, R. T., Felipe, D. G., Marco, A. A. C., \& Maria, K. C. (2017). The grasshoppers (Orthoptera: Caelifera) of the grasslands in the Southern portion of the Espinhaco Range, Minas Gerias, Brazil. Check List, 13(1), 2052. https://doi.org/10.15560/13.1.2052

Caporale, A., Moreno, L. B., Mega, N. O., \& Romanowski, H. P. (2015). Butterflies (Lepidoptera: Papilionoidea and Hesperioidea)of the Banhado dos Pachecos Wildlife Refuge, UruguayanSavanna Ecoregion, Rio Grande do Sul state, Brazil. Checklist, 11(6), 1813. https://doi.org/10.15560/11.6.1813 
Dirsh, V. M. (1965). The African genera of Acridoidea, Cambridge University Press. XIV + $579 \mathrm{pp}$

Gillot, C. (2005). Entomology. Third edition. Springer. 834pp. www.springeronline.com GP - DERUDEP. (2006). Baseline study of the North West Province. 199p

Ladeji, O., Solomon, M., \& Maduka, H. (2003). Proximate chemical analysis of Zonocerus variegatus (Giant Grasshopper). Nigerian Journal of Biotechnology, 14(1), 42-45.

Lecoq, M. (2010). Taxonimie et sytematique des acridiens et principal especes d"Afrique l’ouest. CIRAD, UPR Acridologie, Maroc.

Mestre, J., \& Chiffaud, J. (2009). Acridiens du Cameroun et de la Republique Centrafricaine (Orthoptera: Caelifera). Edition numerique, 172p.

Neba, S. A. (1991). A modern geography of the Republic of Cameroon, 2nd Edition. Ed. Neba, Camden, New Jersy, 211p.

Popov, G. B. (1990). Raising grasshoppers and obtaining egg-pods: A simple method. Surveillance Acridiens au Sahel, 15.

Ronghang, R., \& Ahmed, R. (2010). Edible insects and their conservation strategy in Karbi Anglong District of Assam, North east India. The Bioscan, special issue, 2, 515-521.

Seino, R. A., Dongmo, T. I., Ghogomu, R. T., Kekeunou, S., Chifon, R. N., \& Manjeli, Y. (2013). An inventory of short horned grasshoppers in the Menoua Division, West region of Cameroon. Agricultural and Biology Journal of North America, 4(3), 291-299. https://doi.org/10.5251/abjna.2013.4.3.291.299

Verma, P. S., \& Agarwal, V. K. (2005). Cell Biology, Molecular Biology, Evolution and Ecology. S Chand \& Company Ltd. Ram Nagar, New Delhi 110055. http://www.foodinsectsnewsletter.org/pdfs/W+orldwidespecieslist15sept2011.pdf 2011 insectoid.info/checklist/Acrididae, 2018

\section{Copyright Disclaimer}

Copyright for this article is retained by the author(s), with first publication rights granted to the journal.

This is an open-access article distributed under the terms and conditions of the Creative Commons Attribution license (http://creativecommons.org/licenses/by/4.0/). 